\title{
Nutritional Status During Pregnancy and Relationship with Birth Weight in Cuban Women Estado Nutricional Durante El Embarazo Y Su Relación Con El Bajo Peso Al Nacer En Mujeres Cubanas
}

\author{
Santa Magaly Jiménez*, María Elena Díaz and Armando Rodríguez \\ Department of Epidemiology and Microbiology, Nutrition and Food Hygiene Center of the National Institute of Hygiene, Cuba
}

Submission: November 01, 2019, Published: November 06, 2019

*Corresponding author: Santa Magaly Jiménez Acosta, Department of Epidemiology and Microbiology, Nutrition and Food Hygiene Center of the National Institute of Hygiene, Cuba

\begin{abstract}
Introduction: Both maternal anthropometry and weight gain during pregnancy are important determinants of birth weight. Maternal Body Mass Index in early pregnancy is considered useful for identifying women at nutritional risk.

Objective: To describe MBMI, MWG and anemia during the first and third trimester among different group of age. Assess the relationship of MBMI and MWG on pregnancy outcomes.

Methods: Data were collected from the sentinel sites for maternal nutritional surveillance. information regarding some demographic variables, obstetric history, the newborn weight and mother weight, height and hemoglobin during the first and third trimester were obtained from the patient card. Multinomial logistic regression was carried out examines three level of birth weight with a specific comparison of MBMI, MWG and the presence or absence of anemia.
\end{abstract}

Result: $10 \%$ of mothers had deficient weight entering pregnancy, $15.8 \%$ were overweight and $11.5 \%$ were obese. Women which initiated pregnancy with deficient weight had more normal weight gain than other groups. There is higher level of association between the maternal variables and the weight of the newborn.

Conclusion: The prevalence of maternal obesity is high, with major public health implications and also impacts the health of child. This study showed the relationship between low MBMI and low MWG with low or deficient weight of the newborn.

Keywords: Body mass index; Gestational weight gain; Obstetric outcomes; Neonatal outcomes; anemia, Birth weight

\section{Introduction}

Both maternal anthropometry and weight gain during pregnancy are important determinants of birth weight [1] Maternal Body Mass Index (MBMI) in early pregnancy is considered useful for identifying women at nutritional risk. Maternal weight gain (MWG) in pregnancy can offer a good means of assessing the wellbeing of the pregnant women and by inference of her baby. Inadequate prenatal weight gain is associated with and increased risk of intra-uterine growth retardation, pre-term delivery and low birth weight in infants, and increased perinatal mortality, whereas overweight, obesity and excessive weight gain on the other hand can be associated with high birth weight and, secondarily, prolonged delivery labor, caesarean, birth trauma and other lead adverse ma ternal and fetal outcomes. These have led to suggestions for optimal weight gain to ensure the best outcomes [2-3].

In Cuba, during 2008-10 Diaz ME et al developed an anthropometric reference for Cubans pregnant women that allow the evaluation of physical status at the beginning of pregnancy, the weight gain according to different height ranges and is available in all medical office for prenatal control of pregnant women at primary health care all over the country, allowing classifies mothers according to their nutritional status and monitoring the adequacy of weight gain during gestation [4]. There is another guide to provide either dietetic counseling or food supplements [5]. 
Anaemia in pregnancy is a public health problem with adverse effect in the newborn which could persist during infancy and childhood [6]. In Cuba iron deficiency is the commonest factor. The aims of the present study are to: describe MBMI, MWG and anemia during the first and third trimester among different group of age. Assess the relationship of MBMI and MWG on pregnancy outcomes.

\section{Methods}

Data were collected from the sentinel sites for maternal nutritional surveillance. Expert criteria led the selection of sentinel sites which were distribute in the primary health areas which the highest and the lowest rates for low birth weight scattered through the 15 provinces and the special municipality Isle of Youth. Information regarding some demographic variables (maternal age, educational, level, occupation, and marital status), obstetric history (first prenatal control, parity) and the newborn weight, maternal weight, height and hemoglobin during the first and third trimester were obtained from the patient card of antenatal care.

Information was collected by family doctors previous training for nutritionist personnel of different Hygiene and Epidemiologic Centers of each province. The total number on pregnant after this operation was 3419 . MBMI $\left(\mathrm{Kg} / \mathrm{m}^{2}\right)$ at the beginning of pregnancy was categorized according to Cuban anthropometric references as underweight $(\leq 18.8)$, adequate weight $(>18.8$ a $<25.6)$, overweight $(\geq 25.6 \mathrm{a}<28.6)$ and obese $(\geq 28.6)$. Gestational age was recorder according to the first day of the last normal menstrual period and ultrasound study.

MWG was defined as the difference between the maternal weights measured at the beginning of pregnancy and until week 39 prior to delivery and was grouped into three categories according to the initial MBMI. Is MBMI at the beginning was deficient, low weight gain $(9.45-11.33 \mathrm{~kg})$ adequate weight gain (11.34$17.28 \mathrm{~kg})$ and high weight gain $(\geq 17.29 \mathrm{~kg})$ Is MBMI at the beginning was adequate, low weight gain $(8.64-10.52 \mathrm{~kg})$ adequate weight gain $(10.53-15.93 \mathrm{~kg})$ and high weight gain $(\geq 15.94 \mathrm{~kg})$. Is MBMI at the beginning was overweight, low weight gain (7.56$9.44 \mathrm{~kg})$ adequate weight gain $(9.45-14.85 \mathrm{~kg})$ and high weight gain $(\geq 14.86 \mathrm{~kg}$ ). Is MBMI at the beginning was obese, low weight gain (5.40-7.55kg) adequate weight gain $(7.56-12.96 \mathrm{~kg})$ and high weight gain $(\geq 12.97 \mathrm{~kg})$ [5].

Birth weight was expressed as four categories: $<2500 \mathrm{~g}$ (low birth weight), 2500-2999g (deficient weight) 3000-3999g (adequate) and $\geq 4000 \mathrm{~g}$ (macrosomic). Women enrolled in the study received the standard prenatal care as usual based on health care center protocols. Anaemia was defined as a haemoglobin concentration $(\mathrm{Hb})<110 \mathrm{~g} / \mathrm{L}$ at sea level. Ethics committee approval was obtained from National Institute and Hygiene and Epidemiology.

\section{Statistical Analysis}

All entry data was made by different provinces, and internal consistency checks were performed at the National Center of $\mathrm{Nu}$ trition with a minimum of two cleanness. Descriptive statistics (frequencies, means standard deviation) were used for different variables. Pearson Chi-square test was used to assess association between MBMI, MWG and socio-economic variables. Multinomial logistic regression was carried out examines three level of birth weight (low plus deficient birth weight, adequate and macrosomic) with a specific comparison of MBMI, MWG and the presence or absence of anemia. Data were coded and analyzed using SPSS, version 20 .

\section{Result}

Table 1: Summary of sociodemographic characteristics of pregnant women.

\begin{tabular}{|c|c|c|}
\hline \multirow[t]{2}{*}{ Indicators } & \multicolumn{2}{|c|}{ National Prevalence } \\
\hline & $\mathbf{n}$ & $\%$ \\
\hline $\begin{array}{l}\text { Parity } \\
0 \\
1 \\
2 \\
3 \\
\geq 4\end{array}$ & $\begin{array}{c}112 \\
1372 \\
932 \\
475 \\
526\end{array}$ & $\begin{array}{c}3.3 \\
40.2 \\
27.3 \\
13.9 \\
15.4\end{array}$ \\
\hline $\begin{array}{c}\text { Educational level } \\
\text { Elementary school } \\
\text { Middle school } \\
\text { High school } \\
\text { College }\end{array}$ & $\begin{array}{c}63 \\
741 \\
1659 \\
956\end{array}$ & $\begin{array}{c}1.8 \\
21.7 \\
48.5 \\
28.0\end{array}$ \\
\hline $\begin{array}{l}\text { First prenatal control } \\
\text { Before week } 12 \\
\text { Between } 12-20 \text { weeks } \\
\text { After } 20 \text { weeks }\end{array}$ & $\begin{array}{c}3123 \\
266 \\
30\end{array}$ & $\begin{array}{c}91.3 \\
7.8 \\
0.9\end{array}$ \\
\hline $\begin{array}{l}\text { Marital status of mother } \\
\text { Single } \\
\text { Married or cohabiting }\end{array}$ & $\begin{array}{c}336 \\
3083\end{array}$ & $\begin{array}{c}9.8 \\
90.2\end{array}$ \\
\hline $\begin{array}{l}\text { Mother's occupation } \\
\text { Housewife } \\
\text { Employed } \\
\text { Studying or other }\end{array}$ & $\begin{array}{c}1548 \\
1808 \\
63\end{array}$ & $\begin{array}{c}45.4 \\
52.8 \\
1.8\end{array}$ \\
\hline $\begin{array}{c}\text { Initial BMI } \\
\text { Deficient weight } \\
\text { Adequate weight } \\
\text { Overweight } \\
\text { Obese }\end{array}$ & $\begin{array}{c}342 \\
2146 \\
539 \\
392\end{array}$ & $\begin{array}{l}10.0 \\
62.8 \\
15.8 \\
11.5\end{array}$ \\
\hline $\begin{array}{c}\text { Maternal weight gain } \\
\text { Adequate } \\
\text { Less than adequate } \\
\text { Greater than adequate }\end{array}$ & $\begin{array}{c}1440 \\
1518 \\
461\end{array}$ & $\begin{array}{l}42.1 \\
44.4 \\
13.5\end{array}$ \\
\hline $\begin{array}{c}\text { Anaemia } \\
1^{\text {st }} \text { trimester } \\
3^{\text {rd }} \text { trimester }\end{array}$ & $\begin{array}{l}326 \\
767\end{array}$ & $\begin{array}{c}9.6 \\
22.5\end{array}$ \\
\hline
\end{tabular}

The total number of pregnant women evaluated in sentinel sites during 2015 was 3419 with a mean age of 26.4 years of those $10.7 \%$ were below 20 years and only $2.1 \%$ were above or equal 40 years, majority of women were between 20-29 years age $(61.3 \%)$. The sociodemographic characteristics of pregnant women and nutritional indicators are summarized in Table I. Only $3.3 \%$ of pregnant women with cero parity, whereas $40.2 \%$ reported having one pregnant before. Nearly half of mothers had completed high school educational level and $28 \%$ finished college. Most mothers (90.2\%) were married or living with her boyfriend. Regarding the first prenatal control most women (91.3\%) had at- 
tended the first prenatal control before week 12 and only $0.9 \%$ received this health service after week 20 . According to the mother's occupation $52.8 \%$ were employed and $45.4 \%$ were housewives. $10 \%$ of mothers had deficient weight. About $62.8 \%$ of mothers has a BMI $>18.8$ and $<25.6 \mathrm{~kg} / \mathrm{m}^{2}$ entering pregnancy, $15.8 \%$ were overweight and $11.5 \%$ were obese. Almost $28 \%$ of patients were overweight plus obese Gestational weight gain was adequate in $42.1 \%$ of women whereas $44.4 \%$ had less than adequate weight gain and $13.5 \%$ had excessive gain.

Data on hemoglobin showed that prevalence of anemia increased from the first to the third trimester of pregnancy. The mean height at the first prenatal control was similar in all groups of age. The lowest values were found in women below 20 years $(158.1 \mathrm{~cm})$ and the higher values in women with 40 years or more. The mean weight gain was lower in older women $(9.2 \mathrm{~kg})$ and higher in women below 20 years age (11.39kg) (Table 2).

Table 2: Mean of height, weight gain and hemoglobin according to mother age.

\begin{tabular}{|c|c|c|c|c|c|}
\hline Age & $\begin{array}{c}\text { Num- } \\
\text { ber }\end{array}$ & Height Cm & $\begin{array}{c}\text { Weight } \\
\text { Gain Kg }\end{array}$ & $\begin{array}{c}\text { Hb G/L 1 } \\
\text { Trimester }\end{array}$ & $\begin{array}{c}\text { Hb 3 }^{\text {rd }} \text { Tri- } \\
\text { mester }\end{array}$ \\
\hline$<20$ & \multirow{2}{*}{366} & $\begin{array}{c}158.15 \\
(6.39)\end{array}$ & $\begin{array}{c}11.39 \\
(3.98)\end{array}$ & $\begin{array}{c}120.1 \\
(10.54)\end{array}$ & $\begin{array}{c}114.7 \\
(10.40)\end{array}$ \\
\hline \multirow{2}{*}{$20-29$} & \multirow{2}{*}{2095} & $\begin{array}{c}159.34 \\
(6.50)\end{array}$ & $\begin{array}{c}11.35 \\
(4.0)\end{array}$ & $\begin{array}{c}122.04 \\
(10.50)\end{array}$ & $\begin{array}{c}115.5 \\
(10.26)\end{array}$ \\
\hline \multirow{2}{*}{$30-39$} & \multirow{2}{*}{885} & $\begin{array}{c}159.28 \\
(6.51)\end{array}$ & $\begin{array}{c}10.34 \\
(3.65)\end{array}$ & $\begin{array}{c}120.95 \\
(9.7)\end{array}$ & $\begin{array}{c}115.47 \\
(9.46)\end{array}$ \\
\hline \multirow{2}{*}{40} & \multirow{2}{*}{73} & $\begin{array}{c}160.47 \\
(7.10)\end{array}$ & 9.23 & 121.22 & 114.25 \\
& & $(4.1)$ & $(11.13)$ & $(9.76)$ \\
\hline
\end{tabular}

Mean on hemoglobin in the first and third trimester was higher than the cut off point for determine anemia in all groups of age. Initial BMI and association with weight gain are shown in Table 3. Women which initiated pregnancy with deficient weight had more normal weight gain than other groups. BMI had a significant effect on the weight gain during pregnancy. According to total weight gain by age, groups more than 30 years old showed the greater percentage of weight gain less than ideal (approximately half of women) whereas over gainers' women was observed in greater rates in women with age below 20 years and $20-29$ years, $13,7 \%$ and $14,7 \%$ respectively.

Table 3: Initial BMI and weight gain in pregnant women.

\begin{tabular}{|c|c|c|c|c|c|c|}
\hline & & \multicolumn{5}{|c|}{ Weight Gain } \\
\hline & High & & Low & & Normal & \\
\hline & $\mathrm{n}$ & $\%$ & $\mathrm{n}$ & $\%$ & $\mathrm{n}$ & $\%$ \\
\hline $\begin{array}{c}\text { Deficient } \\
\text { weight }\end{array}$ & 38 & 11.1 & 144 & 42.1 & 160 & 46.8 \\
\hline $\begin{array}{c}\text { Adequate } \\
\text { weight }\end{array}$ & 295 & 13.7 & 938 & 43.7 & 913 & 42.5 \\
\hline Overweight & 69 & 12.9 & 282 & 52.3 & 188 & 34.9 \\
\hline Obese & 59 & 15.1 & 154 & 39.3 & 179 & 45.7 \\
\hline Total & 461 & 13.5 & 1518 & 44.4 & 1440 & 42.1 \\
\hline
\end{tabular}

Chi Square 22,732 $p<0,001$.
Mean weight of newborn according to age of mothers showed that mothers below 20 years age presented higher body weight of newborn $(3427.7 \mathrm{~g} \pm 436.5)$ following by babies from mothers between $20-29$ years $(3340 \mathrm{~g} \pm 459.1)$. Mothers between $30-39$ years old delivered newborns with average weight of $3330.4 \mathrm{~g} \pm 510.8$ and those over 40 years old had babies with $3234.2 \mathrm{~g} \pm 512.2$. Birth weight varied significantly based on MBMI. Women with MBMI $<18.8 \mathrm{~kg} / \mathrm{m}^{2}$ delivered biggest percentage of neonates with birth weight deficient (between 2500-2999g. inverse situation occurred in women with overweight and obese at the beginning of pregnancy those presented the biggest percentage of macrosomic (Table 4).

Table 4: Body mass index at the beginning of pregnancy and birth weight.

\begin{tabular}{|c|c|c|c|c|c|c|c|c|}
\hline BMI & \multicolumn{7}{|c|}{ Birth Weight } \\
\hline & \multicolumn{2}{|c|}{ Low } & \multicolumn{2}{c|}{ Deficient } & \multicolumn{2}{c|}{ Normal } & \multicolumn{2}{c|}{$\begin{array}{c}\text { Macro- } \\
\text { somic }\end{array}$} \\
\hline & $\mathrm{n}$ & $\%$ & $\mathrm{n}$ & $\%$ & $\mathrm{n}$ & $\%$ & $\mathrm{n}$ & $\%$ \\
\hline $\begin{array}{c}\text { Deficient } \\
\text { weight }\end{array}$ & 14 & 4.1 & 86 & 25.1 & 220 & 64.3 & 22 & 6.4 \\
\hline $\begin{array}{c}\text { Adequate } \\
\text { weight }\end{array}$ & 77 & 3.6 & 398 & 18.5 & 1509 & 70.3 & 162 & 7.5 \\
\hline Overweight & 19 & 3.5 & 70 & 13.0 & 376 & 69.8 & 74 & 13.7 \\
\hline Obese & 8 & 2.0 & 50 & 12.8 & 280 & 71.4 & 54 & 13.8 \\
\hline Total & 118 & 3.5 & 604 & 17.7 & 2385 & 69.8 & 312 & 9.1 \\
\hline
\end{tabular}

Chi Square $58,665 p<0.000$

The behavior between parity and MBMI at the beginning of pregnancy showed that women who have never given birth have the highest percentage of deficient weight at the beginning of pregnancy $(66.1 \%)$. However, those that have between 3 and 4 deliveries are those that present the highest prevalence of overweight and obesity, $34.2 \%$ and $27.3 \%$ respectively. Figure 1 shows the comparison between anemia in the first and third trimester by MBMI categories. It is observed that women with adequate nutritional status have a high percentage of anemia. In addition it is observed in smaller amount in all weight categories.

Table 5 showed the estimates and the standard errors of the parameters for the two groups of newborns with inadequate weights by multinomial regression analyses. There are associations between birth weight categories with maternal indicators of nutritional status. The estimated odds ratio $(\exp (ß))$ is presented.

According to the regression analyze, the negative sign of the $§$ parameters estimated in the model implies that a newborn, whose mother has a high MBMI or a high MWG has a less probability that her child has more deficient low weight. On the other hand, children whose mothers had normal or deficient weight are less likely to be macrosomic. Poor weight gain during pregnancy did not show a significant effect on the newborn's macrosomia.

The odds ratio of newborns weighing $<3000 \mathrm{~g}$ whose mothers have a poor weight at the beginning of pregnancy, indicates that they have a higher risk ( 2 times more) of having a child with 
low or deficient birth weight; a woman with a lower weight gain than normal has a probability of 1.4 times to have a newborn with low or deficient weight. The greater probability of having chil- dren with weights more than $4000 \mathrm{~g}$ corresponds to mothers with greater weight gain during pregnancy. Anemia in the third trimester of pregnancy did not have a significant effect on birth weight.

Table 5: Multinomial logistic regression between birth weight and MBMI, MWG and anemia.

\begin{tabular}{|c|c|c|c|c|c|c|}
\hline \multicolumn{7}{|c|}{ Parameter Estimates $^{a}$} \\
\hline \multicolumn{2}{|r|}{ Birth weight } & \multirow{3}{*}{$\begin{array}{c}\text { В } \\
-1,609\end{array}$} & \multirow{3}{*}{$\begin{array}{l}\text { Sig. } \\
, 000\end{array}$} & \multirow{3}{*}{$\operatorname{Exp}(B)$ Low } & \multicolumn{2}{|c|}{ 95\% Confidence Interval for $\operatorname{Exp(B)}$} \\
\hline & & & & & Upper & \\
\hline \multirow{10}{*}{$<3000 \mathrm{~g}$} & Intercept & & & & & \\
\hline & MBMI Obese &,- 084 & ,654 & 919 & ,637 & 1,327 \\
\hline & MBMI Adequate weight &, 321 & ,013 & 1,379 & 1,069 & 1,778 \\
\hline & MBMI Deficient weight & ,694 &, 000 & 2,001 & 1,435 & 2,790 \\
\hline & MBMI Overweight & $0^{\mathrm{b}}$ & . & . & . & . \\
\hline & MWG Greater than adequate &,- 116 & ,429 & ,890 & ,667 & 1,188 \\
\hline & MWG Less than adequate & ,350 &, 000 & 1,418 & 1,186 & 1,697 \\
\hline & MWG Adequate & $0^{\mathrm{b}}$ & . & . & . & . \\
\hline & Anaemia third trimester &,- 080 &, 436 & ,923 &, 754 & 1,130 \\
\hline & No Anaemia third trimester & $0^{\mathrm{b}}$ & . & . & . & . \\
\hline \multirow{10}{*}{$\geq 4000 \mathrm{~g}$} & Intercept & $-1,616$ &, 000 & & & \\
\hline & MBMI Obese &,- 050 & ,799 & ,951 & ,646 & 1,400 \\
\hline & MBMI Adequate weight &,- 631 &, 000 &, 532 & ,394 & ,718 \\
\hline & MBMI Deficient weight &,- 689 &, 008 &, 502 & ,302 & ,833 \\
\hline & MBMI Overweight & $0^{\mathrm{b}}$ & . & . & . & . \\
\hline & MWG Greater than adequate & 608 &, 000 & 1,837 & 1,338 & 2,523 \\
\hline & MWG Less than adequate &,- 134 &, 332 & ,875 & ,668 & 1,146 \\
\hline & MWG Adequate & $0^{\mathrm{b}}$ & . & . & . & . \\
\hline & Anaemia third trimester &,- 212 & ,165 & ,809 &, 599 & 1,091 \\
\hline & No Anaemia third trimester & $0^{\mathrm{b}}$ & . & . & . & . \\
\hline
\end{tabular}

a) The reference category is normal birth weight $(3000 \mathrm{~g}-3399 \mathrm{~g})$.

b) The reference category is normal birth weight (3000g-3399g).

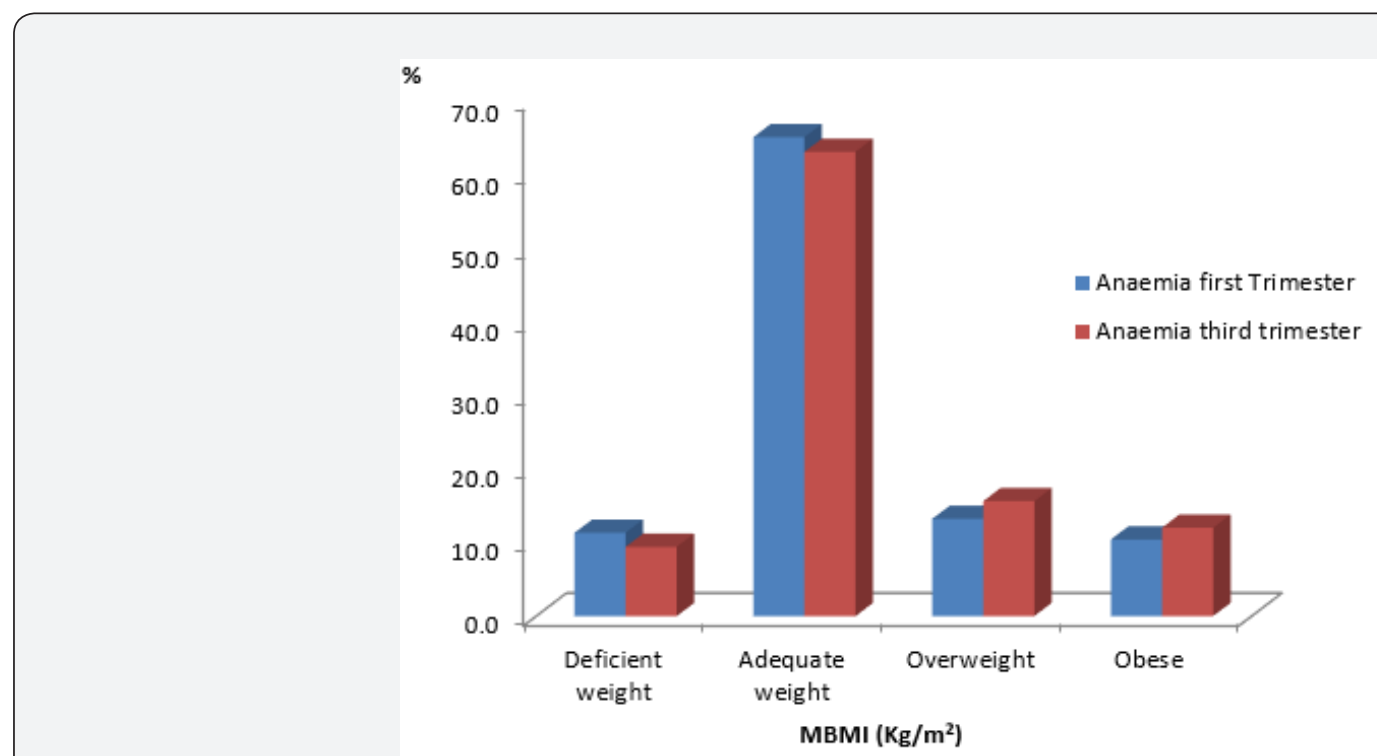

Figure 1: Comparison of anaemia by MBMI. 


\section{Discussion}

Maternal weight is recorded at all prenatal attendances. In Cuba there are as average 15. 8 obstetrics control for 100 inhabitants [7]. Maternal weight gain is considered an important indicator for the following of pregnant women and is frequently discussed by doctors with their patients in consultation and systematically at the primary health care units. Pregnant women under gainers receive different interventions in order to improve the nutritional status and universal iron supplementation is free of charge since the first prenatal control.

It is important to note that majority of women received the first prenatal control before week 12; on the other hand we founded a high proportion of women with high school and college, more than third quarter which is necessary for better efficiency of health educational activities. Prevalence of women with deficient weight at the beginning of pregnancy were lower than in other study in developing country [8].

The prevalence of overweight and obesity has increased dramatically in recent decades including in women of childbearing age [9]. Obesity has been frequently cited as a public health problem in Cuba mainly in women(According to the Third National Risk Factor Survey conducted in 2010-11, in women in childbearing age the prevalence of obesity range between 16.3-34.1\% increasing according to increase of age. Data of the present study (Table 2) found prevalence of obesity similar to reported in survey mentioned above where $12.5 \%$ (IC 95\%: 9,6-15,3) of women between 25-34 years were obese [10].

Obesity during pregnancy may cause adverse outcomes in both mother and child including preeclampsia, cesarean delivery, gestational diabetes, macrosomic babies among other [11] and is a known risk factor for post partum weight retention [12-13]. Some studies have reported relationship between MBMI at the beginning of pregnancy and children's obesity that occurred before 9 years of age [14]. Other researchers demonstrated that obese women have 18-26\% increased chance of delivering large for date infant [15-16]. Because of we used for nutritional assess of pregnant women local references, this makes difficult comparison with other studies carried out in other countries.

Adult height has increased around the world, especially in developed countries, probably due to the improvement in life condition, as we found mean of height in Cuban pregnant women were between $158.1 \mathrm{~cm}$ to $160.5 \mathrm{~cm}$. in different groups of age, it is important because maternal height has an influences on fetal growth. Madrone's founded mean height of $156.3 \mathrm{~cm}$ and $160.09 \mathrm{~cm}$ in women coming from the public and the private health system in Chile, very similar to the present study [17].

In this study the average MWG of women equal or more than 40 years age is lower than others groups. Our data demonstrated that, obese women are more likely to exceed the weight gain recommendations during pregnancy tan other BMI group (Table
4). Atalah et al in a study to quantify risk of obesity in relation to negative event of pregnancy founded that the risk of hypertension, gestational diabetes, late fetal mortality and others was mostly associated with the initial maternal nutritional status in women with $\mathrm{BMI} \geq 30$ [18].

Shao et al suggested that pre-pregnancy MBMI and MWG are independent risk factor for preeclampsia [19].

The prevalence of anemia mainly mild anemia at the time of pregnancy diagnosis in Turk women was 20\% [20]. In the present study in Cuban pregnant women we only founded $9.6 \%$ of anemia at the first trimester.

The percentage of anemia founded was almost three times as high among first compared to third trimester. It can be seen that even women with adequate body weight maintain anemia during pregnancy as well as a triple burden of morbidity. According to WHO criteria, anemia in Cuban pregnant women at third trimester is a moderate public health problem because $22.4 \%$ of this population have anemia, this implies a risk for iron store of outcome [21].

The pooled prevalence of anemia among pregnant women in Ethiopia was $31.6 \%$ almost one-third of pregnant women [22]. During pregnancy iron needs increase substantially to support fetoplacental development and maternal adaptation to pregnancy. Maternal hepcidin concentration is suppressed in the second and third trimesters but the mechanism of maternal hepcidin suppression in pregnancy is unknown. Hormone hepcidin play an important role to meet iron dietary iron absorption and the mobilization of iron from stores [23].

Iron deficiency during pregnancy is associated with a variety of adverse outcomes for both mother and infant, included increased risk of sepsis, maternal mortality and low birth weight [24]. There were a progress in the control of anemia during pregnancy, previous national estimates made by Jiménez et al in 2002 indicated that approximately $27 \%$ of Cubans pregnant women were anemic in the third trimester [25]. Since this date different interventions have been reinforced in Cuba to reduce iron deficiency anemia as a part of the Comprehensive Plan for Prevention and Control iron deficiency anemia [26].

In our study low birth weight prevalence (less than 2500g) is generally low. The reduction in low birth weight is due in part to reinforced nutritional education and the access to a provision of subsidies complementary feeding for all pregnant women at risk of low weight gain, these of course joint to a positive changes in the living conditions for Cuban people.

Birth weight varied significantly based on maternal initial BMI. The current study founded an association between BMI at the beginning of pregnancy and birth weight, the percentage of macrosomic are higher in obese mother in comparison to non obese ones. Salah et al found that the means fetal weight was significantly more in obese mothers compared with other groups [27]. 
The logistic regression model demonstrated the contribution of maternal anthropometry in the newborn deficient weight, indicating that maternal nutritional status and MWG during pregnancy are important predictors of birth weight deficit. However for macrosomia the only important factor is the high weight gain during pregnancy. The absence of significance of the model proposed in the analysis of the contribution of maternal obesity and the deficient weight gain during pregnancy in macrosomic newborns does not correspond with those expected in other studies [28].

The anemia of the third trimester did not provide information to be taken into consideration to evaluate the somatometric status of the newborn.

\section{Limitation}

The limitations of this study lies in the fact that the data collection was retrospective through sentinel sites, despite the fact that they were located with good selection and sampling criteria.

\section{Conclusion}

The prevalence of maternal obesity is high, with major public health implications and also impacts the health of child. This study showed the relationship between low MBMI and low MWG with low or deficient weight of the newborn.

\section{Acknowledgement}

The authors wish to thank to different sentinel sites in the 15 provinces.

\section{Competing Interest}

The authors declare that they have not competing interest.

\section{Funding}

The sentinel sites project was supported by the Ministry of Public Health from Cuba.

\section{References}

1. Rasmussen KM, Yaktine AL (2009) Institute of Medicine (US) and National Research Council (US) Committee to Reexamine IOM Pregnancy Weight Guidelines. Weight Gain during Pregnancy: Reexaming the 3Guidelines. National Academy Press: Washington, DC, USA.

2. Marsoosi V, Jamal A, Eslamian L (2004) Pre-pregnancy weight, low pregnancy weight gain, and preterm delivery. Int J Gynaecol Obstet 87(1): 36-37.

3. Abrams B, Altman SL, Pickett KE (2000) Pregnancy weight gain: still controversial. Am J ClinNutr 71(5 suppl): 1233S-1241S.

4. Díaz Sánchez ME (2012) Nutrición y embarazo. En: Colectivo de autores. Obstetricia y perinatología. Diagnóstico y tratamiento. La Habana, ECIMED, Cuba.

5. Díaz ME, Jiménez S, Gamez AI, Pita G, Puentes I, et al. (2013) Consejos útiles sobre la alimentación y nutrición de la embarazada. Manual para profesionales de la Salud. Editorial Lazo Adentro, La Habana, Cuba.

6. Goonewardrdene M, Shehata M, Hamad A (2012) Anaemia in pregnancy. Best Pract Res Clin Obstet Gynaecol 26(1): 3-24.

7. Ministerio de Salud Pública de Cuba (2017) Anuario Estadístico de Sa- lud 2016. La Habana, Cuba.

8. Soltani H, Lipoeto NI, Fair FJ, Kilner K, Yusrawati Y, et al. (2017) Pre-pregnancy body mass index and gestational weight gain and their effects on pregnancy and birth outcomes: a cohort study in West Sumatra, Indonesia. BMC Womens Health 17(1): 102.

9. Felming T, Robinson M, Thomson B, Graetz N, Margano C, et al. (2014) Global, regional and national prevalence of overweight and obesity in children and adults during 1980'2013: a systematic analysys for the Global Burden of Disease Study 2013. Lancet 384(9945): 766-781.

10. Díaz Sánchez María Elena (2014) Evaluación antropométrica. En: Bonet Gorbea Mariano. III Encuesta Nacional de factores de riesgo y actividades preventivas de enfermedades no transmisibles. Cuba 20102011, ECIMED, La Habana, Cuba, pp. 106-135.

11. American College of Obstetricians and Gynecologist (2013) ACOG committee opinion no. 549. Obesity in pregnancy. Obstet Gynecol 121(1): 213-217.

12. Mannan M, Doi SA, Mamum AA (2013) Association between weight gain during pregnancy and post partum weight retention and obesity: a bias adjusted meta-analysis. Nutr Rev 71(6): 343-352.

13. Bodnar LM, Siega-Riz AM, Simhan HN, Himes KP, Abrams B, et al. (2010) Severe obesity, gestational weight gain and adverse birth outcomes. Am J Clin Nutr 91(6): 1642-1648.

14. Gale CR, Javaid MR, Robinson SM, Law CM, Godfrey KM, et al. (2007) Maternal size in pregnancy and body composition in children J Endocrinol Metab 92(10): 3904-3911.

15. Kiran UTS, Hemmadi S, Bethel J, Evans J (2005) Outcome of pregnancy in a woman with an increased body mass index. BJOG 112(6): 768-772.

16. Sebine NJ, Jolly M, Harris JP, Wadsworth J, Joffe M, et al. (2001) Maternal obesity and pregnancy outcome: a study of 287,213 pregnancies in London. Int J Obes Relat Metab Disord 25(8): 1175-1182.

17. Mardones F, Tapia JL, Mallea R, Villarroel L (2004) Talla de mujeres adultas gestantes en muestras de los sistemas de salud público y privado de Chile. Rev Med Chile 132(12): 1483-1488.

18. Atalah E, Castro R (2004) Obesidad materna y riesgo reproductive. RevMed Chile 132(8): 923-930.

19. Shao Y, Qiu J, Huang H, Mao B, Dai W, et al. (2017) Pre pregnancy BMI, gestational weigt gain and risk of preeclampsia: a birth cohort study in Lanzhou, China. BMC Pregnancy childbirth 17(1): 400.

20. Ozturk M, Ozturk O, Ulubay M, Karasahin E, Ozgurtas T, et al. (2017) Anemia prevalence at time of pregnancy detection. Turk J Obstet Gynecol 14(3): 176-180.

21. Benoist DB, Lean ME, Egli I, Cogswell M (2008) Worldwide prevalence of anaemia 1993-2005. World Health Organization, Geneva, Switzerland.

22. Kassa GM, Muche AA, Berhe AK, Fekadu GA (2017) Prevalence and determinant of anemia among pregnant women in Ethiopia; a systematic review and meta-analysis. BMC Hematol 17: 17.

23. Fisher AL, Nemeth E (2017) Iron homeostasis during pregnancy. Am J ClinNutr 106(Supl 6): 1567S-1574S.

24. Nazanin A, Hurrell R, Kelishadi R (2014) Review on iron and its importance for human health J Res Med Sci 19(2): 164-174.

25. Jiménez S, Monterey P, Plasencia D (2002) Sitios centinela: su aplicación en la vigilancia nutricional materna en Cuba. Rev Esp Nutr Comunitaria 8(3-4): 95-100.

26. Ministry of Public Health (CU) (2008) Plan integral para la prevención y el control de la anemia por deficiencia de hierro en Cuba. Havana. Ministry of Public Health (CU), Spanish. 
27. Salah RA, Mostafa AA, Osman AM, Heshan M (2009) Prepregnancy obesity ond pregnancy outcome. Int J Health Sci (Qassim) 3(2): 203-208.
28. Addo VN (2010) Body mass index, weight gain during pregnancy and obstetric outcomes. Ghana Med J 44(2): 64-69.

\section{Your next submission with Juniper Publishers will reach you the below assets}

- Quality Editorial service

- Swift Peer Review

- Reprints availability

- E-prints Service

- Manuscript Podcast for convenient understanding

- Global attainment for your research

- Manuscript accessibility in different formats

( Pdf, E-pub, Full Tsext, Audio)

- Unceasing customer service

Track the below URL for one-step submission https://juniperpublishers.com/online-submission.php 